\title{
NOTES
}

\section{CHANGE OF STATUS OF A PARTY TO A COLLECTIVE LABOR AGREEMENT}

THE relationship created by a collective agreement is frequently disturbed by changes in parties. Changes in the employer typically result from such transactions as the sale or lease of a plant, ${ }^{1}$ sale of all the assets of a company, ${ }^{2}$ and merger or consolidation. ${ }^{3}$ Changes in the union frequently stem from gradual shifts of membership due to individual resignations, ${ }^{4}$ transfers to rival groups, and expulsions. But mass switches also contribute to union changes. Thus, the employees may formally dissolve their local or disaffiliate it from the national. Either occurrence is usually a step in the process of mass affiliation with another national. ${ }^{6}$ Other changes in the union may arise from revocation of the local's charter by the national7 or a schism in the local or the

1. See, e.g., Application of Swift \& Co., 76 N.Y.S.2d 881 (Sup. Ct. 1947) (purchase of plant; vendee refused to assume predecessor's obligations and therefore not compelled to arbitrate severance pay dispute).

2. See, e.g., Empire Case Goods Workers Union v. Empire Case Goods Co., 271 App. Div. 149, 63 N.Y.S.2d 35 (4th Dep't 1946).

3. See, e.g., Commercial Telegraphers' Union v. Western Union Tel. Co., 53 F. Supp. 90 (D.D.C. 1943).

Other types of employer changes may include reorganization of a corporation or a partnership, death of an individual proprietor, and receivership and bankruptcy proceedings. For lists of cases dealing with the effects of these changes on contracts in general, see Notes, 149 A.L.R. 787 (1944); 59 A.L.R. 294 (1929).

4. A representative may lose its bargaining position if it loses the allegiance of the majority of the members of the bargaining unit. See the decertification procedure provided in the amended NLRA $\$ 9$ (c), 61 StaT. 144 (1947), 29 U.S.C. \$159(c) (Supp. 1950). For an example, see Walker County Hosiery Mills, 91 N.L.R.B. No. 7 (1950).

5. Frequently, workers join a new union while they still maintain membership in the contracting organization. See, e.g., In re Grant Bldg., Inc., 45 Pa. D. \& C. 442 (C.P. 1942). This is especially true when a union security contract is in effect. See, e.g., Triboro Coach Co. v. NYSLRB, 286 N.Y. 314, 36 N.E.2d 315 (1941).. Labor organizations often expel members who are guilty of dual unionism. See, e.g., Federal Electric Products Co., 1 Lab. Arb. Rep. 13, 17 Lab. ReL. Rep. (Ref. Man.) 2685 (1945).

6. See, e.g., Black-Clawson Co., 63 N.L.R.B. 773 (1945) (formal dissolution); Liquid Carbonic Corp., 85 N.L.R.B. 284 (1949) (disaffiliation). Occasionally, following formal dissolution, the employees may choose to remain without a bargaining agent. Or they may later form one or more new locals with varying national affiliations. But a local which enjoys majority status is not likely to dissolve unless the members wish to shift en masse to a rival, or to form an independent. If the workers lose interest in unionization, the local is more likely to dwindle in membership. Eventually, it will be dissolved when only a handful of members are left or it will become defunct without formal action. See, e.g., Container Corp. of America, 61 N.L.R.B. 823 (1945). Of course, company-dominated organizations with majority membership may be disbanded by formal collective action as a result of unfair labor practice proceedings against the employer. See, e.g., Wyman-Gordon Co. v. NLRB, 153 F.2d 480 (7th Cir. 1946).

7. See, c.g., in re Klinger, 259 App. Div. 309, 19 N.Y.S. 2d 193 (1st Dep't 1940). 
nationa1. ${ }^{8}$ Many of these shifts may be precipitated when a national union secedes or is expelled from a federation and continues as a going organization. ${ }^{0}$

When a change occurs in either of the parties to a valid collective agreement, several important problems arise as to the rights and duties of the continuing and altered parties subsequent to the change. ${ }^{10}$ After a change in union, under what circumstances may the original contracting local retain recognition as the exclusive bargaining agent? After a change in employer or union, may the continuing party require the new party to assume the contract? And may the new party enforce the agreement against the continuing party?

The existing handful of judicial decisions indicates that a slight pattern may be emerging. Traditional doctrines of sanctity, privity, and freedom of contract generally prevail even though the results of their application may be inconsistent with the basic objectives of the national and state labor relations laws-freedom of association, collective bargaining, and avoidance of interruptions in commerce resulting from interference with these rights. ${ }^{11}$ The policy of the labor acts may be most seriously affected where the employer or the abandoned union has attempted to prevent the new or dissident organization from acting as bargaining agent.

In New York, courts will enforce contracts between an employer and a successor union when the union "by process of evolution or reorganization [has] inherited the powers, assets and membership" of its contracting predecessor. ${ }^{12}$ The "inheritance" requirement is satisfied when the successor union is the result of an amalgamation, ${ }^{13}$ or when a union merely changes its name and affiliation. ${ }^{14}$ But the claim of a union that it represents a majority of the old

8. See, e.g., Foiey Lumber \& Export Corp., 70 N.L.R.B. 73 (1946) (local).

9. For example, the expulsion from the CIO of the United Electrical, Radio and Machine Workers of America (UE) on November 2, 1949, was immediately followed by the formation of the International Union of Electrical, Radio and Machine Workers (IUE-CIO). A large percentage of UE's membership shifted to IUE through formal dissolutions of locals, schisms in locals and individual shifts. A deluge of court actions and board proceedings has followed. See, e.g., Fitzgerald v. Kriss, 25 LAB. REL. REP. (Ref. Man.) 2337 (N.D.N.Y. 1950) (creation of competing local); Fitzgerald v. Elsner, 25 LAB. REx. REP. (Ref. Man.) 2140 (S.D. Ohio 1949) (formal dissolution); Telex Inc., 90 N.L.R.B. No. 43 (1950) (individual withdrawals); Hoover Co., 90 N.L.R.B. No. 265 (1950) (decertification proceedings).

10. For general discussions of the problem, see Comment, 51 YaLE L.J. 465 (1942); Note, 63 HARv. L. Rev. 1413, 1423-6 (1950).

11. See declaration of policy, amended NLRA $\$ 1,61$ Stat. 136 (1947), 29 U.S.C. $\S 151$ (Supp. 1950).

12. In re Klinger, 259 App. Div. 309, 310, 19 N.Y.S.2d 193, 194 (1st Dep't 1940).

13. Monyoky v. Fairchild Engine \& Airplane Corp., 112 N.Y.L.J. 1563, 15 LAB. Rec. Rep. (Ref. Man.) 683 (N.Y. Sup. Ct. 1944); Anderson v. Universal Brass Turning Co., 10 LAB. Ret. REP. (Ref. Man.) 902 (N.Y. Sup. Ct. 1942).

14. World Trading Corp. v. Kolchin, 166 Misc. 854, 855, 2 N.Y.S.2d 195 (N.Y. Sup. Ct. 1938) (union's "identity, structure, operation, constitution, by-laws, officers and membership are still the same ...."). Cf. NLRB v. Harris-Woodson Co., 179 F.2d 
union's members is not sufficient in itself to show the necessary privity. ${ }^{15}$ And this is also true where the union claims to have been established by a national organization to replace a local whose charter was revoked. ${ }^{16}$

Elsewhere, courts have stressed the affiliation between the local and parent and the relation of both to the employer. Thus, suspension of a local's charter by a national union does not permit the employer to disregard his contract with the local where the national is neither a party to the contract nor mentioned in it. ${ }^{17}$ But where the agreement specifically mentions the national affiliation of the contracting local or includes the national as a signatory party, the seceding group is not permitted to act as a contracting party. ${ }^{18}$ And the

720 (4th Cir. 1950) (employer not relieved of duty to bargain with majority representative when latter changes its name and affiliation).

15. Morrison v. Majestic Laundry System, Inc., 103 N.Y.S.2d 791 (Sup. Ct. 1951) (local formed by seceding majority denied decree substituting it for contracting local as administrator of collective agreement); Weiss v. Fields Shops, Inc., 8 LAB. REL. ReP. (Ref. Man.) 1064 (Sup. Ct. 1941).

16. In re Klinger, 259 App. Div. 309, 19 N.Y.S.2d 193 (1st Dep't 1940). Although it is still unclear whether a new union will be bound by the contract of its predecessor, New York courts might apply the inheritance principle in this area also.

At first, the National Labor Relations Board required a newly certified union to take over an existing contract. New England Transportation Co., 1 N.L.R.B. 130 (1936). More recently, the Board has declined to decide the fate of the old agreement, leaving it to negotiation between the parties, or to the courts. See, e.g., Boston Machine Works Co., 89 N.L.R.B. No. 17 (1950) (all prior opinions to the contrary expressly overruled).

A proposed section of the House Bill to revise the NLRA provided that a newly certified representative must assume the contract of the old bargaining agent for the remainder of the contract term. This provision was rejected in committee. H.R. REP. No. 510, 80th Cong., 1st Sess. 50 (1947).

17. Montaldo v. Hires Bottling Co., 59 Cal. App. 2d 642, 139 P.2d 666 (3rd Dist. 1943) (court rejected employer's contention that suspension constituted failure of consideration). Cf. Louisville Ry. Co. v. Louisville Area Transport Workers Union, $312 \mathrm{Ky} .657,228$ S.W.2d 652 (1950) (national union not a party to contract could not block local's assignment of its contract to independent union which majority of local's members had joined).

18. $M$ \& $M$ Woodworking Co. v. Plywood \& Veneer Workers Local Union No. 102, 23 F. Supp. 11 (D. Ore. 1938); M \& M Woodworking Co. v. NLRB, 101 F.2d 938 (9th Cir. 1939), setting aside 6 N.L.R.B. 372 (1938) ; Mason Mfg. Co. v. United Furniture Workers of America, Local No. 576, 2 LAB. ReL. REP. (Ref. Man.) 839 (Calif. Super. Ct. 1938). See also Suffridge v. O'Grady, 84 N.Y.S.2d 211 (Sup. Ct. 1948) (deserted national allowed to administer welfare fund established by contract).

The court of appeals implied in the second $M \& M$ case that the new majority might have been recognized as contracting party if the local's disaffiliation had been accomplished in strict compliance with the union constitution. 101 F.2d 938, 941 (9th Cir. 1939). This, however, will be of little value to future secessionists. Disaffiliation clauses in union constitutions are generally so drafted that it is almost impossible for a local to withdraw as a unit in accordance with their terms. Typically, the clause permits a very small number of members, loyal to the parent, to retain the local's charter in the face of an overwhelming majority vote for disaffiliation or dissolution. See, e.g., General Laws, 
employer can invoke the union security provisions to throw the seceding workers out of their jobs. ${ }^{18}$ The courts regard retention of the stipulated affiliation as a condition of continued employment. And it makes no difference that all of the signatory company's employees have switched to the rival organization. The contracts were made for the benefit of all the members of the national union, not merely for those employed by the signatory companies. Therefore, if a worker leaves the organization contrary to the agreement, other members of the national have a right to his job. ${ }^{20}$

Some courts have gone so far as to uphold enforcement of a closed shop contract with the signatory union even after a rival union was certified as exclusive bargaining agent by the state labor relations board. ${ }^{21}$ These decisions were based on the feeling that employees should not be allowed to repudiate their obligations by replacing their representatives during the life of a valid agreement. $^{22}$

$\S 25$, of United Brotherhood of Carpenters and Joiners, quoted at 101 F.2d 938, 941 (9th Cir. 1939) (ten members clause).

In addition, many national constitutions place onerous penalties on withdrawal. Thus, they may provide that if a local secedes, its monies and property are to be delivered to the parent body upon demand. See, e.g., United Public Workers of America v. Local 312, 94 F. Supp. 538 (E.D. Mich. 1950). The courts will generally enforce these constitutions as valid contracts between the organizations and the members. Schnitzler v. Scida, 27 Lab. Rez. ReP. (Ref. Man.) 2025 (E.D.N.Y. 1950). Contra: Harker v. McKissock, 10 N.J. Sup. Ct. 26, 76 A.2d 89 (1950). But several courts have recently refused to enforce similar provisions of the UE constitution. The rationale advanced was that the effectiveness of these constitutional provisions is subject to an implied condition of continued affiliation with the CIO. And since UE has been expelled from the CIO they are no longer enforceable against the local unions. Local 1140 of UE v. UE, 45 N.W.2d 408 (Minn. 1950).

19. See cases cited in first paragraph of note 18 supra. But compare Mason Mfg. Co. v. United Furniture Workers of America, Local No. 576, 2 LAB. REc. REP. (Ref. Man.) 839 (Calif. Super. Ct. 1938), with Mason Mfg. Co., 15 N.L.R.B. 295 (1939), modified and enforcement granted, 126 F.2d 810 (9th Cir. 1942) (state court approved employer's enforcement of closed shop contract upon disaffiliation. But the employer's action was held to be an unfair labor practice by NLRB and federal Court of Appeals). These cases, and the $M \& M$ cases cited in the first paragraph of note 18 supra, illustrate an early conflict between courts and boards. The boards were primarily concerned with the uncoerced selection of employee representatives. The courts, of course, generally had the final word.

20. Mason Mfg. Co. v. United Furniture Workers of America, Local No. 576, 2 Lab. Ret. Rep. (Ref. Man.) 839 (Cal. Super. Ct. 1938); of. Pennsylvania LRB v. Red Star Shoe Repairing Co., 2 LAB. Ret. Rep. (Ref. Man.) 882 (Pa. C.P. 1938).

21. Triboro Coach Corp. v. NYSLRB, 286 N.Y. 314, 36 N.E.2d 315 (1941); and see Labarge v. Malone Aluminum Corp., 6 LAB. REL. REP. (Ref. Man.) 1073 (N.Y. Sup. Ct. 1940) (certification by NLRB).

22. Triboro Coach Corp. v. NYSLRB, 286 N.Y. 314, 322, 36 N.E. $2 d$ 315, 318 (1941). To the same effect, see cases cited in first paragraph of note 18 supra.

During the life of the old agreement, the courts permit the certified union to negotiate a new agreement to take effect at the expiration of the old one. See Triboro Coach Corp. v. NYSLRB, supra; Johnson v. Bee Lines, Inc., 262 App. Div. 762, 27 N.Y.S.2d 
At first blush, protecting the existing contract under the administration of the signatory union may seem to promote industrial stability. Actually, it is also likely to cause strife. If courts refuse to give effect to the new choice of the majority of the employees, a strike for recognition may follow. ${ }^{23}$ And even if the new majority group does not stop work, the repudiated union is unlikely to achieve much success in administering the contract and processing grievances. Employee resentment and unrest are likely to mount, with an accompanying decrease in productivity.

Moreover, an employer may be caught in a crossfire of conflicting directives. This clash can arise not only between courts and state labor boards, but also between courts and the NLRB. For the NLRB places greater stress on the statutory right of free choice of bargaining agent than on traditional contract doctrines. Thus, the Board has directed an election and certified a new union in the face of a court order enforcing the old union's contract. ${ }^{24}$ And it has found an unfair labor practice when an employer refused to bargain with a certified union because a state court order restrained the employer from breaching his contract with a rival organization. ${ }^{25}$

732, 733 (2d Dep't 1941), reversing 8 LAB. Ret. Rep. (Ref. Man.) 1081 (N.Y. Sup. Ct. 1941).

23. The likelihood and legality of a strike for recognition following the decision was noted by both the majority and the dissenters in Triboro Coach Corp. v. NYSLRB, 286 N.Y. 314, 322, 338-9, 349, 36 N.E.2d 315, 318, 325-6, 330 (1941). And the strike did in fact take place. New York Times, Aug. 9, 1941, p. 17, col. 1.

A strike for recognition by an uncertified union is legal under the amended NLRA unless (1) the strike is against an employer other than the one from which recognition is sought, or (2) another union is already certified. $\$ 8(\mathrm{~b}), 61$ STAT. 141 (1947), 29 U.S.C. $\$ 158$ (b) (4) (B) and (C) (Supp. 1950).

24. Presto Recording Corp., 34 N.L.R.B. 28, 36 N.L.R.B. 281 (1941) (directing election and certifying winner in face of court order enforcing contract of rival union); Pacific Box Co., 50 N.L.R.B. 720 (same); Air Conditioning Co. of Southern California, 81 N.L.R.B. 946 (1949) (in processing representation petition, Board refused to await outcome of pending suit); Libby, McNeill \& Libby, 64 N.L.R.B. 30 (1945) (same). The Board feels that its duty to determine bargaining agents cannot be affected by a contract action in a state court. Air Conditioning Co. of Southern California, supra at 949 .

25. The Grace Co., 84 N.L.R.B. 435 (1949). Where the identity of the majority union was in dispute, the Board has ordered an employer to disavow a contract in spite of a court decree of specific enforcement. National Electric Products Corp., 3 N.L.R.B. 475, 500-3 (1937) (decree of U.S. District Court for W.D. Pa. entered July 29, 1937). And in Mason Mfg. Co., 15 N.L.R.B. 295 (1939), modified and enforcement granted, 126 F.2d 810 (9th Cir. 1942), the Board, in an unfair labor practice proceeding, declared invalid a contract that was ruled valid by a state court. Accord: Williams Mfg. Co., 6 N.L.R.B. 135 (1938); cf. NYSLRB v. Holland Laundry, Inc., 294 N.Y. 480, 63 N.E.2d 68 (1945) (previous court finding in injunction proceeding that contract was valid not res judicata in subsequent New York labor board unfair labor practice proceeding). But where a contract was already in effect, one state court has enjoined enforcement of another agreement even though it was negotiated with a union certified by the N.L.R.B. Labarge v. Malone Aluminum Corp., 6 LAB. REL. REp. (Ref. Man.) 1073 (N.Y. Sup. Ct. 1940). 
Where the question is one of a replacing employer's rights and duties under an existing agreement, a distinction may be drawn between a merger or consolidation and an ordinary sale. Upon a merger or consolidation, the collective agreement of each firm probably will continue to be binding on both the resulting corporation and the signatory unions. ${ }^{26}$ The contract signed by the surviving company before a merger will not be imposed upon the employees of the absorbed corporation. ${ }^{27}$ Similarly, when a corporation buys out another company other than by merger or consolidation, the transferee's employees will not be compelled to abandon their old union and join the organization with which their new employer has signed a union security contract. ${ }^{28}$ But, contrary to the merger-consolidation situation, it is not likely that their new employer would be able to hold the incoming employees to a contract they had signed with their predecessor employer. And some courts have held that unless a successor employer voluntarily assumes his predecessor's labor agreement, he will not be required to honor it. ${ }^{29}$ This may be true even where management of the business remains substantially the same, ${ }^{30}$ and where the sale is admittedly an attempt to get out from under a labor agreement. ${ }^{31}$

26. There is no clear authority for this statement, but see Commercial Telegraphers' Union v. Western Union Tel. Co., 53 F. Supp. 90 (D.D.C. 1943) (federal statute). By statute in all states, the surviving or resulting corporation assumes the debts and liabilities of the merged or consolidated corporations. Bariantine, Corporations $\$ \$ 289,294$ (Rev. ed. 1946) ; Note, 149 A.L.R. 787, 801 (1944). Generally, executory contracts pass to the new company. Ducasse v. American Yellow Taxi Operators, Inc., 224 App. Div. 516, 231 N.Y. Supp. 511 (2d Dep't 1928).

Language in the Commercial Telegraphers' case suggests that the union continues to be bound by its contract in merger and consolidation cases. $53 \mathrm{~F}$. Supp. 90, 96-7 (D.D.C. 1943).

27. Commercial Telegraphers' Union v. Western Union Tel. Co., 53 F. Supp. 90 (D.D.C. 1943).

28. NYSLRB v. Club Transportation Corp., 275 App. Div. 536, 90 N.Y.S.2d 367 (2d Dep't 1949).

29. Empire Case Goods Workers Union v. Empire Case Goods Co., 271 App. Div. 149, 63 N.Y.S.2d 35 (4th Dep't 1946); Application of Swift \& Co., 76 N.Y.S.2d 881 (Sup. Ct. 1947) ; accord Herman Loewenstein, Inc., 75 N.L.R.B. 377 (1947); Douglas Aircraft Co., 27 WAR LaB. REP. 7 (1945).

30. Good Foods, Inc. v. Loupos, 5 LAB. ReL. REp. (Ref. MIan.) 936 (N.J.Ch. 1939) (newly formed corporation purchased business from insolvent firm; predecessor's manager, who signed contract with union, continued to act as manager).

31. Berry v. Old South Engraving Co., 283 Mass. 441, 186 N.E. 601 (1933) (business sold to new corporation organized by officers and stockholders of selling corporation).

A New York court reached an opposite result when a partnership tried to avoid a collective agreement by forming a corporation. Goldman v. Rosenzweig, $10 \mathrm{LAw}$ \& LABOR 207 (N.Y. Sup. Ct. 1928) (court enjoined old employers from repudiating contract and enjoined new employer from directing or counseling violation of contract, without deciding whether new employer was bound by it).

An employer cannot avoid its duty to bargain with a majority union, or to remedy unfair labor practices by transferring the business to a new firm which is the "alter ego" of the old one. NLRB v. O'Keefe \& Merritt Mfg. Co., 178 F.2d 445 (9th Cir. 1949); 


\section{Proposed Solution}

Whenever doubt arises as to whether a change has occurred in either of the parties to a collective agreement, two basic questions must be answered: with whom should the other party deal; and, if one of the original parties has been replaced, should the old contract continue in effect. Courts should tackle the first question by refusing to enforce a collective agreement by or against a union which is not entitled to act as bargaining agent of the employees concerned. ${ }^{32}$ Whenever a court is faced with a dispute over which union, if any, is entitled to act as bargaining agent, the court should direct the parties to petition the National Labor Relations Board for a determination of representatives. ${ }^{33}$ Whether the Board directs an election or dismisses the petition, its action will normally decide which organization is the exclusive representative. ${ }^{34}$ Pending the outcome of the representation proceeding, the agreement

Autopart Mfg. Co., 91 N.L.R.B. No. 11 (1950). And a certification may be amended to apply to a new employer which purchased the assets of the original company and continues to operate the plant in the same manner and with the same employees. Miller Lumber Co, 90 N.L.R.B. No. 185 (1950).

An employer's liability on a contract will ordinarily terminate with its ownership. Amelotte v. Jacob Dold Packing Co., 173 Misc. 477; 17 N.Y.S.2d 929 (Sup. Ct. 1940), aff'd 260 App. Div. 984, 24 N.Y.S.2d 134 (4th Dep't 1940). But where the employees are deprived of the benefit of their bargain by the contracting employer's fraud or misrepresentation, the latter may be held liable. Thus when a partnership was incorporated in an attempt to avoid a labor agreement, the partners were ordered to abide by the contract's terms. Goldman v. Rosenzweig, supre. And an employer which concealed the fact that it had sold its business until after contract benefits on which the employees relied had become due was required to pay the benefits. Empire Case Goods Workers Union v. Empire Case Goods Co., 271 App. Div. 149, 63 N.Y.S.2d 35 (4th Dep't 1946) (paid vacations). An employer which failed to bind its vendee to a labor contract as required by the terms of the instrument, was ordered to arbitrate, under that contract, the question of whether it must pay damages to employees discharged by the successor. Application of Swift \& Co., 76 N.Y.S.2d 881 (N.Y. Sup. Ct. 1947).

32. For cases on specific enforcement of collective agreements, see Note, 156, A.I.R. 652 (1945).

When the action is for damages for a past breach, the criterion should be whether the union was entitled to act as representative at the time of the alleged breach. It should make no difference whether it is presently entitled to act.

33. For the statutory provisions on the determination of representatives, see amended NLRA $\$ 9$ (c), 61 Stat. 144 (1947), 29 U.S.C. $\$ 159$ (c) (Supp. 1950). Of course, the parties could on their own initiative petition the NLRB to settle disputes over the proper bargaining representative before they ask the courts for specific performance.

34. Even the dismissal of a petition by the Board will often determine who is the exclusive representative. For example, where the Board, after certifying one union as the exclusive representative, refuses to hold another election until the termination of the contract entered into by that union, see note 38 infra, the Board's action is equivalent to a determination that the original union is to remain as exclusive representative for the contract period. In other situations where the Board dismisses a petition, however, its action will not determine who is the proper bargaining agent and the court will have to settle that question for itself. For example, the Board will 
should be administered by the contracting union. ${ }^{35}$ However, if there is doubt as to which union is the contracting union, the court should designate one or both of the unions to administer the agreement. The court might also wish to impound the funds and other assets of the contracting union pending the NLRB decision, in order to prevent their being misused in the interim. ${ }^{36}$

In deciding whether to conduct an election, the Board is governed by its contract bar doctrine. ${ }^{37}$ Under that doctrine the Board usually will not disturb a collective agreement of reasonable duration. ${ }^{38}$ It will refuse to entertain representation petitions in the bargaining unit covered until shortly before the contract termination date. During the contract period a new union will not be certified, even if the contracting union has lost its majority status. ${ }^{39} \mathrm{~A}$ determination of representatives will be directed in spite of an existing contract,

not hold a representation election if all the competing unions have failed to comply with the filing and affidavit requirements of amended NLRA $\$ \S 9(f),(g)$, and $(h), 61$ STAT. 145-6 (1947), 29 U.S.C. $\$ \$ 159(\mathrm{f}),(\mathrm{g})$, and (h) (Supp. 1950), for non-complying unions are barred from the ballot in such elections. Herman Loewenstein, Inc., 75 N.L.R.B. 377 (1947). But cf. Harris Foundry \& Machine Co., 76 N.L.R.B. 118 (1948) (non-compliance did not keep union off ballot in decertification election). Similarly, where the Board dismisses a petition on jurisdictional grounds, the court will either have to decide itself who is the proper bargaining agent or refer the matter to a state labor relations board.

35. See, e.g., Elsner v. General Motors Corp., 25 LAB. ReL. Rep. (Ref. Man.) 2514 (Ohio C.P. 1950) (injunction to preserve the status quo; employer ordered to deal with committeemen elected before schism until NLRB determination).

It might be advisable for the Board to give priority to cases referred to it by the courts. In that way, the necessity for a Board determination would not unduly delay a court decision.

36. For a discussion of the theories on which courts settle rival claims to union property, see Notes, 58 Y ALE L.J. 1171 (1949); 63 HARv. L. REv. 1413, 1414-20 (1950). See also Huntsman v. McGovern, 91 N.E. 2d 717 (Ohio C.P. 1949), where, following the UE-CIO schism, the court ordered that funds from dues, collections and other assets be impounded until the issuance of an NLRB decision.

37. It is also governed by $\S 9$ (c) (3) of the Taft-Hartley Act, which provides that no election shall be directed in any bargaining unit within which, in the preceding twelve-month period, a valid election has been held. 61 Stat. 144 (1947), 29 U.S.C. $\$ 159$ (c) (3) (Supp. 1950). For the Board's policy as to unions which have not complied with the Act's filing and affidavit requirements, see note 35 supra.

38. Reasonable duration currently means two years, International Paper Co., 80 N.L.R.B. 751 (1948), unless contracts for longer terms are customary in the industry. California Walnut Growers Assn., 77 N.L.R.B. 756 (1948). If the contract is for an unreasonably long or indefinite term, it will be protected only during its initial two years. Rheinstein Construction Co., 88 N.L.R.B. 46 (1950); Association of Motion Picture Producers, Inc., 88 N.L.R.B. 521 (1950).

39. E.g., Elwood Machine \& Tool Co., 61 N.L.R.B. 1618 (1945) (over 80\% of employees expressed desire to change bargaining representatives by voting at a meeting, petition, and authorization cards); Montgomery Ward \& Co., 68 N.L.R.B. 369 (1946) (testimony that contracting union's membership had fallen to about 5\% of the employees in the unit); Telex, Inc., 90 N.L.R.B. 43 (1950) (election denied because there was no formal collective action to disaffiliate). 
however, when the contracting union is defunct. ${ }^{40}$ In addition, an election will usually be held when a formal mass disaffiliation or schism results in "doubt as to the identity" of the representative ${ }^{41}$ or "breakdown in the normal bargaining relationship." 42

Whenever the Board invokes one of these exceptions and displaces a contracting union, courts should regard that union as stripped of all prospective rights and obligations under the agreement. ${ }^{43}$ This will automatically give full effect to the latest official expression of majority preference by the employees. It will also ensure that an employer will no longer be faced with conflicting obligations to honor a contract with one union and bargain collectively with another.

Similarly, upon being replaced, an employer's liability under the contract normally should cease. However, a retiring employer should remain responsible for breaches which he has caused or aggravated. ${ }^{44}$ And the employer should also continue to be liable for that portion of accruing obligations, like severance and vacation pay, which have accrued during the time he was party to the agreement. ${ }^{45}$

If one of the contracting parties is replaced, the object of the law should be to promote stability by preventing the usual hiatus in contractual relations. An existing agreement should continue in effect until its termination date under the administration of the new employer or the newly certified bargaining agent, unless the parties revise it by mutual consent. ${ }^{46}$ Most provisions of the contract should be as applicable to the new relationship as to the old, requiring only a change of names and titles. Even a union shop provision in the agreement should present no special difficulty. The Taft-Hartley Act

40. E.g., Rock City Paper Box Co., 82 N.L.R.B. 746 (1949).

41. E.g., Rubber Corp. of America, 88 N.L.R.B. 922, 923 (1950); Liquid Carbonic Corp., 85 N.L.R.B. 284 (1949).

42. E.g., Boston Machine Works, 89 N.L.R.B. No. 17 (1950); Bowen Products Corp., 89 N.L.R.B. No. 20 (1950). But cf. Telex, Inc., 90 N.L.R.B. No. 43 (1950) (no election). But even then, an election may be denied if the change of affiliation is induced by an active raiding campaign by a rival. Owen-Illinois Pacific Coast Co., 36 N.L.R.B. 990 (1941).

43. Of course, the displaced union should still be capable of suing and being sued upon causes of action that arose under the contract prior to the termination of its bargaining agency.

44. See notes 25 and 26 supra. The replaced employer should also have a cause of action for damages for breaches occurring before the change.

45. See, e.g., In re Brooklyn Citizen, 23 LAB. ReL. Rep. (Ref. Man.) 2429 (N.Y. Sup. Ct. 1949) (dissolution); Empire Case Goods Workers Union v. Empire Case Goods Co., 271 App. Div. 149, 63 N.Y.S.2d 35 (4th Dep't 1946) (sale of business).

46. The War Labor Board required a successor to assume a contract when its relationship to the predecessor was a close one, as in reorganization and merger. Snow Lumber Co., 24 W AR LAB. REP. 306 (1945) (partnership formed by ex-stockholders of contracting corporation); Geilich Tanning Co., 20 WAR LAB. REP. 353 (RWLB 1, 1947) (successor union); National Munitions Co., 14 WAR LAB. REP. 644 (RWLB 3, 1944) (same officers, product, employees, ownership). 
permits an employer and a union to agree to a union shop, provided the union is authorized to make such an agreement by a majority vote of the eligible employees. ${ }^{47}$ This vote should be construed as a continuing authorization to whatever labor organization is the duly certified representative of the employees concerned, until the employees rescind the authorization. Thus if one union replaces another as the certified representative and the employees do not take affirmative action under $\S 9(\mathrm{e})(2)^{48}$ to reject a previously authorized union shop, the union shop provisions in the existing agreement should operate automatically in favor of the new union. ${ }^{49}$

Of course a change in one of the parties to a collective agreement may be accompanied by other changes which render parts of the agreement obsolete or inadequate. For example, a shift in employers may result in changes in the business or operations and in the creation of new jobs. But changes of this sort can occur just as readily without any shift in parties. And in this area it may be undesirable, perhaps almost impossible, to prescribe a complete set of rules in advance for the problems which may arise. Each situation is an extraordinary and pathological case; each is enmeshed in unique circumstances pulling in a variety of directions. Usually at least some of the problems must be solved before authoritative determination from a governmental agency can be had; the business and the employment cannot be suspended for the months or years which a proceeding for such a determination requires. Uusually, therefore, the parties involved manage-despite the strains and difficulties and sometimes with the aid of ad hoc interlocutory orders-to reach amicable adjustment at least on the matters controlling future operations. 0

47. Amended NLRA $\$ \$ 8(a)(3)$ and 9(e), 61 Stat. 140, 144 (1947), 29 U.S.C. $\S \S 158$ (a) (3), 159(e) (Supp. 1950). These provisions also apply to maintenance of membership agreements. General Electric Corp., 81 N.L.R.B. 476 (1949).

48. Section $9(\mathrm{e})(2)$ of the Taft-Hartley Act provides that if $30 \%$ or more of the employees in a bargaining unit covered by a union shop agreement file a petition alleging their desire that the union shop authorization be rescinded, the Board is to take a secret ballot of such employees. 61 STAT. 144 (1947), 29 U.S.C. $\$ 159$ (e) (2) (Supp. 1950). Section $9(\mathrm{e})(3)$, however, further provides that "[n]o election shall be conducted pursuant to this subsection $[9(\mathrm{e})]$ in any bargaining unit or any subdivision within which, in the preceding twelve-month period, a valid election shall have been held." 61 STAт. 144 (1947), 29 U.S.C. $\$ 159$ (e) (3) (Supp. 1950).

49. In similar fashion, any check-off provisions in the agreement should be automatically carried over to the successor union. This could be accomplished by regarding the employee's written assignment under LMRA $\$ 302$ (c) (4), 61 STAT. 157 (1947), 29 U.S.C. $\$ 186$ (c) (4) (Supp. 1950), as an assignment in favor of whatever union is the duly certified representative.

50. In many cases, the contract itself will provide for reopening certain provisions when circumstances change. And grievance machinery or arbitration procedures in the agreement may afford an avenue for alteration or reinterpretation of existing clauses to fit current needs. The extent to which these procedures may be used to alter the contract varies widely, depending on the provisions of the contract. Compare Northland Greyhound Lines, Inc. v. Amalgamated Assn., 66 F. Supp. 431 (D.C. Minn. 1946), 
The function of the law can be only to announce quite general principles by way of encouragement rather than command. And it is submitted that the preferable principles would be that (a) as a general rule a change of party of the kind discussed is not a method for terminating or avoiding a collective agreement; (b) such a change made for other reasons may, however, necessarily affect the collective agreement involved; (c) the new parties should be under a duty, and normally would desire, to negotiate on these effects; (d) but these negotiations should and can be carried out on the premise that the existing agreement is to continue to the extent that it can be applied-that is, with regard to the circumstances which have not been changed by the change of party-and that amendments are required to the extent that the change of party has created new or changed conditions requiring joint treatment. ${ }^{51}$

and Southern Colorado Power Co., 28 WAR LAB. REP. 157 (1945), with In re American Dietaids Co., 21 LAB. ReL. Rep. (Ref. Man.) 2508 (N.Y. Sup. Ct. 1948).

51. Section 8(d) of the Taft-Hartley Act, 61 STAт. 142 (1947), 29 U.S.C. \$158(d) (Supp. 1950), should not be construed as relieving the union or employer from a duty to bargain in good faith about changes in the existing contract necessitated by a shift in parties. Nor should it prevent the union or employer from resorting to strike or lock-out in the event those negotiations break down.

Section 8 (d) provides in part that the duty to bargain collectively means that "no party to such contract shall terminate or modify such contract, unless the party desiring such termination or modification-

(1) serves a written notice upon the other party to the contract of the proposed termination or modification sixty days prior to the expiration date thereof ... ; $\ldots$ and

(4) continues in full force and effect, without resorting to strike or lock-out, all the terms and conditions of the existing contract for a period of sixty days after such notice is given or until the expiration date of such contract, whichever occurs later..." [Italics added]

The section goes on to specify, however, that the fourth requirement (as well as the second and third, omitted from the passage quoted above) "shall become inapplicable upon an intervening certification" of the NLRB, under which the union that is a party to the contract "has been superseded as or ceased to be" the representative of the employees concerned. Thus when one union has displaced another as the certified representative, neither the new union nor the employer need comply with 8 (d) (4). Furthermore, the NLRB has refused to interpret 8(d) (4) literally. Rather the Board has construed it merely as "prohibit[ing] a strike to secure modification or termination of a collective agreement for a period which is limited to 60 days after a proper notice of the proposed modification or termination has been given." United Packinghouse Workers of America (CIO), 25 LAB. REL. REP. (Labor-Management) 1556, 1560 (1950). The Board felt that a literal interpretation of the section would thwart Congressional intent, for "[n]owhere in the legislative history is there any indication of an intent to extend the statutory waiting period beyond the 60 days to which reference is repeatedly made." Id. at 1559. Thus where a union or employer feels that a shift in parties has necessitated changes in the existing contract, and wishes to press its position by resorting to strike or lock-out, the most that is required under the Board's interpretation of 8 (d) (4) is that the strike or lock-out be deferred until 60 days after the giving of notice under 8 (d) (1). 